\title{
A COMPARATIVE STUDY ON OXYTOCICS IN THE ACTIVE MANAGEMENT OF THIRD STAGE OF LABOUR
}

\author{
Suvidha Saurabh', Arif Md. Rohan², Md. Aftabuddin Mondal 3 , Shyamapada Pati ${ }^{4}$ \\ 1 Junior Resident, Department of Obstetrics and Gynaecology, Calcutta National Medical College, Kolkata. \\ 2Junior Resident, Department of Pharmacology, IMS \& SUM Hospital, Bhubaneswar. \\ ${ }^{3}$ Assistant Professor, Department of Obstetrics and Gynaecology, Calcutta National Medical College, Kolkata. \\ ${ }^{4}$ Professor, Department of Obstetrics and Gynaecology, Calcutta National Medical College, Kolkata.
}

\section{ABSTRACT}

\section{BACKGROUND}

A number of oxytocic drugs are recommended for prevention of postpartum haemorrhage. Different studies claim superiority of one drug over the other with conflicting results.

Aim- With this background, synthetic oxytocin IM, Inj. Methergine IM and Tab. Misoprostol P/R were used in 3 groups to observe their effects on blood loss, duration of $3^{\text {rd }}$ stage of labour, need for additional uterotonics and adverse effects.

\section{MATERIALS AND METHODS}

Settings and Design- Tertiary care centre, Kolkata. Clinical trial, non-randomised with single blinding.

A total of 150 uncomplicated pregnant mothers divided into 3 groups of 50 each were administered inj. Synthetic Oxytocin (Syntocinon) 10 units IM (Group A), Inj. Methergine $0.2 \mathrm{mg}$ IM (Group B) and Tab. Misoprostol $600 \mathrm{mcg}$ P/R (Group C) immediately after delivery of the baby. Vaginal blood was collected in a special receptacle (BRASS-V-DRAPE). Blood loss, duration of $3^{\text {rd }}$ stage, additional uterotonics and adverse effects were noted.

Statistical Analysis- With Statistical Analysis Software (SPSS, Version 16) using ANOVA test followed by Post hoc, Tukey test.

\section{RESULTS}

Blood loss and duration of $3^{\text {rd }}$ stage were least with Oxytocin and maximum with Misoprostol with Methergine in between. Additional uterotonics were more often needed with Misoprostol when compared with the other two (Statistically significant). Adverse effects with oxytocin was least.

\section{CONCLUSION}

Synthetic oxytocin has more advantages and less side effects compared to other oxytocics used in the study. However, additional uterotonics should be in hand.

\section{KEYWORDS}

Oxytocics, Oxytocin, Methergine, Misoprostol, PPH, Uterotonics.

HOW TO CITE THIS ARTICLE: Saurabh S, Rohan AM, Mondal MA, et al. A comparative study on oxytocics in the active management of third stage of labour. J. Evolution Med. Dent. Sci. 2017;6 (43):3395-3398, DOI: 10.14260/Jemds/2017/735

\section{BACKGROUND \\ Postpartum haemorrhage (PPH) with prevalence of 6 to $11 \%{ }^{1-2}$ is a major killer in Obstetrics. Active management of $3^{\text {rd }}$ stage of labour (AMTSL), recommended by FIGO, ICM and $\mathrm{WHO}^{3}$, is highly effective at preventing PPH among facility based deliveries. ${ }^{4}$ Oxytocics are recommended immediately following delivery. Syntocinon, Methergine, Misoprostol and Prostaglandin $\left(\mathrm{PGF}_{2} \alpha\right)$ have been used in different studies, claiming advantages, efficacy and side effects of one or the other with regards to reduction of blood loss, shortening of duration of $3^{\text {rd }}$ stage of labour, reduction in the incidence of PPH and side effects. ${ }^{5-9}$ \\ This clinical trial was conducted using Syntocinon (synthetic oxytocin) 10 units IM, Methylergometrine (Methergine) $(0.2 \mathrm{mg} / \mathrm{mL}) \mathrm{IM}$ and Tab. Misoprostol (PGE analogue $-600 \mu \mathrm{g}$ ) per rectum -}

Financial or Other, Competing Interest: None.

Submission 24-04-2017, Peer Review 18-05-2017,

Acceptance 24-05-2017, Published 29-05-2017.

Corresponding Author:

Dr. Md. Aftabuddin Mondal,

29/1, Doctor Lane, Kolkata - 700014.

E-mail: aftabuddinmondal5@gmail.com

DOI: $10.14260 /$ jemds $/ 2017 / 735$ i. To observe their effects in reducing blood loss in third stage of labour.

ii. To note their effect on the duration of third stage of labour.

iii. To observe the need for additional uterotonics.

iv. To note the adverse effects of these pharmacological agents.

\section{MATERIALS AND METHODS}

This clinical trial was carried out in the Department of Obstetrics and Gynaecology, Calcutta National Medical College and Hospital since April 2015 to March 2016 with a total of 150 cases, divided into three groups (A, B, C), each group comprising 50 cases. The sample size was kept small (50 in each group) purposefully for the convenience of the PG students as it was a PG dissertation study. The cases were subjected to 3 drugs (Syntocinon, Methergine and misoprostol) each drug being administered to 50 cases. Study design was non-randomised with single blindness as the patients were not aware of the medicine used. It was a clinical trial.

Selection criteria - i) Low risk singleton pregnancies, ii) gestational age $>37$ weeks, iii) Longitudinal lie, iv) Parity $\leq 3$. Exclusion criteria- i) Pregnancies with any high risk factor 
including $\mathrm{Hb}<8 \mathrm{~g} \%$, ii) intrauterine foetal death and iii) coagulation abnormalities. Term pregnancies both booked and unbooked, admitted through OPD or emergency were subjected to thorough history taking, examination and investigations. Details of management were noted. Blood loss collection tool used to assess post-delivery bleeding was with BRASS V DRAPE [Fig. 1]. It was developed by NICHD global network UMKC/JNMC/UIC collaborative team to specifically estimate blood loss in postpartum 48 hours. The drape has a calibrated and funnelled collecting pouch incorporated within a plastic sheet that is placed under the buttocks of the patient immediately after delivery of the baby. The upper end of the sheet has a belt for tying loosely around the abdomen of the woman [Fig. 2].

\section{Procedure}

- On admission into the labour room, pre-delivery vital signs and $\mathrm{Hb} \%$ were recorded.

- First and second stages of labour were monitored.

- $\quad$ Calibrated BRASS-V-DRAPE was kept under the buttocks after the delivery of the baby so that blood could collect in the receptacle.

- Umbilical cord was clamped, cut and baby handed over.

- Oxytocic drug was administered by the assistant immediately after delivery of the baby - Syntocinon, Methergine and misoprostol to 50 mothers of group A, B and $\mathrm{C}$ respectively.

- Time interval between delivery of the baby and delivery of the placenta was noted.

- Blood collected in the BRASS-V-DRAPE was measured and recorded. Any PPH was noted and managed. Any additional uterotonic, when needed was administered.

- Pulse, temperature and BP were recorded one hour after delivery.

- Any complaint like nausea, vomiting, shivering, fever, headache and diarrhoea were noted.

- Repeat Hb estimation was done 24 hours after delivery.

\section{Ethics}

Ethical clearance was obtained from the Institutional Ethics Committee before undertaking the study.

Statistical analysis was done with Statistical Analysis Software (SPSS Version 16) using ANOVA test followed by Post hock Test, Turkey test.

$\mathrm{X}^{2}$ was not done as many cells were empty which made the test invalid.

\section{RESULTS}

A total of 150 cases were studied. Demographic variables in the three groups are shown in table 1 . The women in the three groups are comparable with regards to age, weeks of gestation and parity.

Events in labour are shown in table 2. Oxytocin has shortest duration of $3^{\text {rd }}$ stage followed by Methergine, with misoprostol having longest duration [ $p$ value between Group $A \& B=0.002$, between Group B and $C=0.0001$ and between Group $\mathrm{A}$ and $\mathrm{C}=0.0001$ statistically significant]. PPH was diagnosed in 2, 5, \& 10 cases with oxytocin, Methergine, and misoprostol respectively.

Need for additional uterotonics was maximum with misoprostol. It was not statistically significant between Group A and Group B ( $p=0.097)$ but significant between Group B and Group C ( $p=0.048)$ and between Group A and group C ( $p$
$=0.0005)$. Blood transfusion for PPH was not required in the 2 cases of Group A but was needed in one out of 5 cases of Group B and 3 out of 10 cases of Group C. Mean pre-delivery and post-delivery $\mathrm{Hb}$ difference in all the groups were not statistically significant. $(\mathrm{p}=0.07)$.

Side effects with different oxytocics are shown in Table 3. Headache, nausea, vomiting, hypertension and pyrexia are more common with Methergine whereas shivering and diarrhoea were more common with Misoprostol. Oxytocin had least side effects of all.

\begin{tabular}{|c|c|c|c|}
\hline Parameters & $\begin{array}{c}\text { Group A } \\
\text { (Oxytocin } \\
\mathbf{n = 5 0 )}\end{array}$ & $\begin{array}{c}\text { Group B } \\
\text { (Methergine } \\
\mathbf{n = 5 0}\end{array}$ & $\begin{array}{c}\text { Group C } \\
\text { (Misoprostol } \\
\mathbf{n = 5 0}\end{array}$ \\
\hline Mean age & $25.48 \pm 2.87$ & $25.34 \pm 2.59$ & $25 \pm 2.56$ \\
\hline $\begin{array}{c}\text { Average weeks } \\
\text { of gestation }\end{array}$ & $38.64 \pm 0.93$ & $38.77 \pm 0.74$ & $38.66 \pm 0.59$ \\
\hline $\begin{array}{c}\text { Parity } \\
0\end{array}$ & 22 & 26 & 23 \\
$\geq 1$ & 28 & 24 & 27 \\
\hline \multicolumn{2}{|c|}{ Table 1. Demographic Variables in the Study Population } \\
\hline
\end{tabular}

\begin{tabular}{|c|c|c|c|}
\hline Parameters & $\begin{array}{c}\text { Group A } \\
\text { (Oxytocin } \\
\text { n= 50) }\end{array}$ & $\begin{array}{c}\text { Group B } \\
\text { (Methergine } \\
\mathbf{n}=\mathbf{5 0} \text { ) }\end{array}$ & $\begin{array}{c}\text { Group C } \\
\text { (Misoprostol } \\
\text { n = 50) }\end{array}$ \\
\hline $\begin{array}{l}\text { Duration of } 3^{\text {rd }} \\
\text { stage (min.) } \\
\text { (Mean) }\end{array}$ & $5.32 \pm 0.92$ & $6 \pm 0.84$ & $7.41 \pm 1.01$ \\
\hline $\begin{array}{c}\begin{array}{c}\text { Blood loss } \\
(\mathrm{mL})\end{array} \\
\end{array}$ & $257.14 \pm 0.92$ & $307 \pm 96.441$ & $385 \pm 113.68$ \\
\hline $\begin{array}{c}\text { PPH (Blood } \\
\text { loss }>500 \mathrm{~mL} \text { ) }\end{array}$ & 2 & 5 & 10 \\
\hline $\begin{array}{c}\text { Mean Hb } \\
\text { (g/dL) } \\
\text { Pre-delivery } \\
(1) \\
\text { Post-delivery } \\
(2) \\
\text { Av. Difference } \\
\text { (1-2) } \pm \text { SD } \\
\end{array}$ & $\begin{array}{c}10.98 \\
10.70 \\
0.26 \pm 0.17\end{array}$ & $\begin{array}{c}11.01 \\
10.77 \\
0.26 \pm 0.13\end{array}$ & $\begin{array}{c}10.71 \\
10.56 \\
0.22 \pm 0.09\end{array}$ \\
\hline $\begin{array}{c}\text { Need for } \\
\text { additional } \\
\text { uterotonics }\end{array}$ & 2 & 5 & 10 \\
\hline $\begin{array}{c}\text { Blood } \\
\text { transfusion }\end{array}$ & Nil & 1 & 3 \\
\hline
\end{tabular}

\begin{tabular}{|c|c|c|c|}
\hline Side effects & $\begin{array}{c}\text { Group A } \\
\text { (Oxytocin } \\
\mathbf{n = 5 0 )}\end{array}$ & $\begin{array}{c}\text { Group B } \\
\text { (Methergine } \\
\mathbf{n = 5 0}\end{array}$ & $\begin{array}{c}\text { Group C } \\
\text { (Misoprostol } \\
\mathbf{n = 5 0}\end{array}$ \\
\hline Headache & 0 & 2 & 1 \\
\hline Hypertension & 1 & 3 & 1 \\
\hline Nausea & 1 & 2 & 0 \\
\hline Vomiting & 1 & 2 & 0 \\
\hline Pyrexia & 1 & 4 & 1 \\
\hline Shivering & 1 & 1 & 3 \\
\hline Diarrhoea & 0 & 0 & 4 \\
\hline Total & $\mathbf{5}$ & $\mathbf{1 4}$ & $\mathbf{1 0}$ \\
\hline Table 3. Side Effects with Different Oxytocics \\
\hline
\end{tabular}




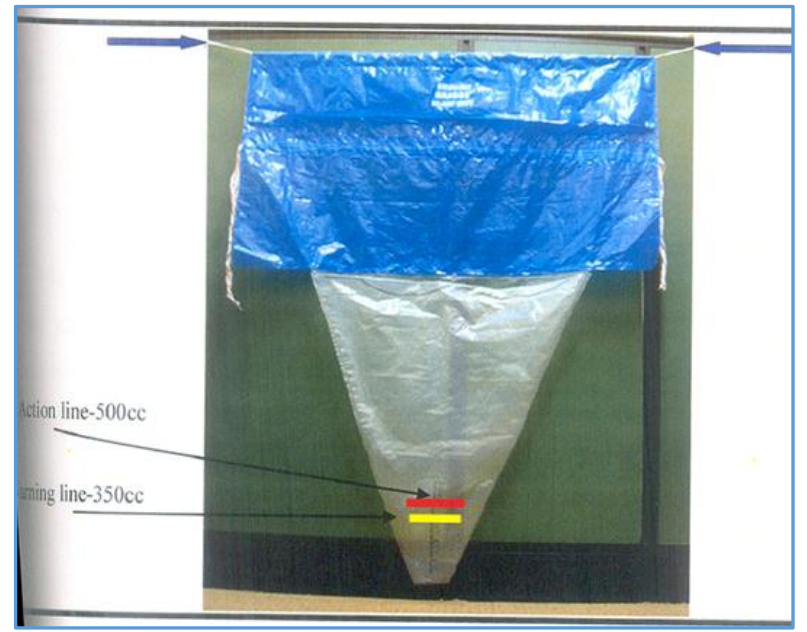

Figure 1. BRASS -V -Drape Used for Collection of Vaginal Blood after Delivery of the Baby. It Allows Better Objective Assessment of Blood Loss

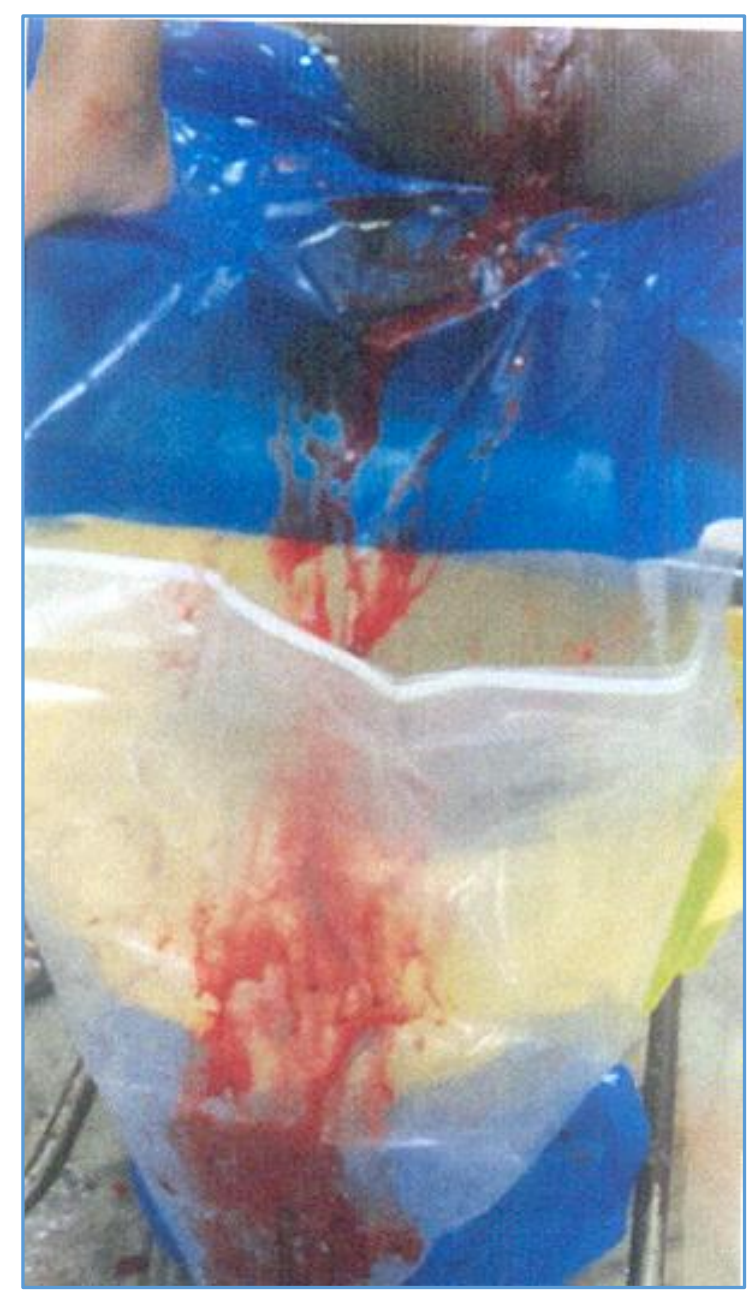

Figure 2. BRASS-V-Drape Placed Under the Buttocks Collects Blood after Delivery of the Baby

\section{DISCUSSION}

Age, parity and gestational age as noted in our study is similar to other institutional studies in India.5,10 In our observation, duration of third stage of labour was the shortest with oxytocin followed by Methergine, with Misoprostol having longest duration. Oxytocin and Methergine were found equally effective in one study ${ }^{6}$ whilst Methergine was found more effective in another study. ${ }^{5}$
However, oxytocin was found superior to Misoprostol in another study. ${ }^{11}$

Regarding reduction of blood loss in the present study, Oxytocin was most effective and Misoprostol least. Observation of a study at $\mathrm{Nepal}^{7}$ with oxytocin and Misoprostol was similar to ours, but at a study in Himachal Pradesh, ${ }^{9}$ both were found equally effective. Comparison between oxytocin and Methergine was contrary to ours in the studies by Ezaemaco et al and at SSG Medical College, Gujarat. ${ }^{5}$ These inconsistent findings may partly be due to different other methods adopted in estimating blood loss, some are less accurate and inconsistent and many studies included induced labour.

Difference in the pre and post-delivery mean $\mathrm{Hb}$ was not statistically significant in the present study, similar to other studies.5,6

Oxytocin group had least number of PPH in the present study similar to Saito et al from Japan. This is dissimilar to Gohil et $\mathrm{al}^{5}$ and a Nigerian study. Dissimilarity is partly due to other less accurate method of estimation of blood loss as well as due to difference in the amount of blood loss in defining $\mathrm{PPH}$.

In the present study, need for blood transfusion was nil with Oxytocin, 2\% with Methergine and 6\% with Misoprostol, in contrast to Gohil T.J. ${ }^{5}$ with $1 \%, 1 \%$ and $7 \%$ respectively.

Headache and hypertension, nausea, vomiting and pyrexia noted with Methergine in our study is also similar to other studies. ${ }^{5}$, Shivering observed with Misoprostol in our study was also the observation of Shrestha et al.7 Shivering and diarrhoea with Misoprostol observed in the present study was also the observation of Gohil et al. ${ }^{5}$

\section{Summary}

- A total of 150 cases were divided into 3 groups of 50 each. Group A - Inj. Oxytocin 10 units IM, Group B - Inj. Methergine $0.2 \mathrm{mg}$ IM and Group C - Tab. Misoprostol $600 \mu \mathrm{g}$ P/R. Measurement of blood loss was done with more accurate device (BRASS-V-DRAPE).

- Age, parity and gestational age were comparable.

- Blood loss and duration of $3^{\text {rd }}$ stage were least with oxytocin and maximum with misoprostol with Methergine in between.

- Additional uterotonic was more often needed with misoprostol when compared with oxytocin and Methergine (statistically significant). More cases needed additional uterotonic after Methergine than oxytocin though not statistically significant.

- $\quad$ Adverse effects were least with oxytocin though frequent with Methergine (headache, nausea, vomiting and hypertension) and misoprostol (shivering and diarrhoea).

- Blood loss and PPH with need for blood transfusion was least with oxytocin, intermediate with Methergine and maximum with misoprostol.

\section{CONCLUSION}

Oxytocics used for active management of labour are useful in reducing postpartum haemorrhage, and shortening the duration of labour. Of the oxytocics, synthetic oxytocin has advantages over others in reducing blood loss and shortening duration of labour with less side effects, less need for additional uterotonics and less need for blood transfusion. 


\section{ACKNOWLEDGEMENT}

We are grateful to the Principal and Medical Superintendent cum Vice Principal, Calcutta National Medical College and Hospital and West Bengal University of Health Sciences for allowing the study.

\section{REFERENCES}

[1] Caroli G, Cuesta C, Abalos E, et al. Epidemiology of postpartum haemorrhage: a systematic review. Best Pract Res Clin Obst Gynaecol 2008;22(6):999-1012.

[2] Calvert C, Thomas SL, Ronsmans C, et al. Identifying regional variation in the prevalence of $\mathrm{PPH}$ : a systematic review and meta-analysis. PLOS One 2012;7(7):e41114.

[3] Chanrachakul BB, Herabutya Y, Panburana P. Active management of labour: is it suitable for a developing country? Int Journal of Gynecol Obstet 2001;72(3): 229-34.

[4] Prendville WJP, Elbourne D, McDonald SJ. Active versus expectant management of $3^{\text {rd }}$ stage labour. The Cochrane Database Syst Rev 2000;(3):CD000007.

[5] Gohil JT, Tripathi B. A study to compare the efficacy of Misoprostol, Oxytocin, Methyl-ergometrine and Ergometrine-Oxytocin in reducing blood loss in AMTSL. The Journal of Obstetrics and Gynaecology of India 2011;61(4):408-12.
[6] Adhikari S, Rana A, Bista KD, et al. Active management of 3rd stage labour. Comparison between prophylactic intramuscular methylergometrine and intramuscular oxytocin. N J Obstet Gynaecol 2007;2(2):24-8.

[7] Shrestha A, Dongol A, Chawla CD, et al. Rectal misoprostol versus intramuscular oxytocin for prevention of PPH. Kathmandu University of Medical Journal 2011;9(33):8-12.

[8] Amant F, Spitz B, Timmerman D, et al. Misoprostol compared with methylergometrine for the prevention of postpartum haemorrhage: a double-blind randomised trial. $\mathrm{Br} \mathrm{J}$ Obstet Gynaecol 1999;106(10):1066-70.

[9] Narrey N, Mahajan N, Vij A, et al. Rectal misoprostol vs intramuscular oxytocin for prevention of PPH. J of Evolution of Medical and Dental Sciences 2015;4(55):9606-12.

[10] Sharma M, Kaur P, Kaur K, et al. A comparative study of oxytocin/misoprostol/methylergometrine for active management of $3^{\text {rd }}$ stage of labour. J Obstet Gynaecol India 2014;64(3):175-9.

[11] Lumbiganon P, Villar J, Piaggio G, et al. Side effects of misoprostol during first 24 hours after administration in the $3^{\text {rd }}$ stage of labour. BJOG 2002;109(11):1222-6. 